\title{
Aminoglycoside- and Cisplatin-Induced Ototoxicity: Mechanisms and Otoprotective Strategies
}

\author{
Corné J. Kros ${ }^{1}$ and Peter S. Steyger ${ }^{2,3}$ \\ ${ }^{1}$ Sussex Neuroscience, School of Life Sciences, University of Sussex, Falmer, Brighton BN1 9QG, \\ United Kingdom \\ ${ }^{2}$ Oregon Hearing Research Center, Oregon Health \& Science University, Portland, Oregon 97239 \\ ${ }^{3}$ National Center for Rehabilitative Auditory Research, VA Portland Health Care System, \\ Portland, Oregon 97239 \\ Correspondence: c.j.kros@sussex.ac.uk; steygerp@ohsu.edu
}

\begin{abstract}
Ototoxicity refers to damage of inner ear structures (i.e., the cochlea and vestibule) and their function (hearing and balance) following exposure to specific in-hospital medications (i.e., aminoglycoside antibiotics, platinum-based drugs), as well as a variety of environmental or occupational exposures (e.g., metals and solvents). This review provides a narrative derived from relevant papers describing factors contributing to (or increasing the risk of) aminoglycoside and cisplatin-induced ototoxicity. We also review current strategies to protect against ototoxicity induced by these indispensable pharmacotherapeutic treatments for life-threatening infections and solid tumors. We end by highlighting several interventional strategies that are currently in development, as well as the diverse challenges that still need to be overcome to prevent drug-induced hearing loss.
\end{abstract}

S pecific medications to treat life-threatening $S$ conditions as well as several other compounds can cause a debilitating side effect-ototoxicity (i.e., the permanent loss of hearing or balance) (Table 1). The socioeconomic cost of ototoxicity has to be weighed against the benefits of surviving severe infections or cancer. In this review, we focus on two clinically essential drugs, the aminoglycosides and cisplatin, both of which remain widely used despite the risk of ototoxicity.

Aminoglycosides, including gentamicin, amikacin, kanamycin, and tobramycin, are broad-spectrum antibiotics used for treating suspected or confirmed acute serious infections, and the long-term management of recurrent respiratory infections in cystic fibrosis and multidrug-resistant tuberculosis (Escobar et al. 2000; Garinis et al. 2017a; Jiang et al. 2017). The ototoxicity of the first aminoglycoside discovered, streptomycin (Schatz et al. 1944), was recognized soon after its initial use (Hinshaw and Feldman 1945). Newer aminoglycosides have varying degrees of cochleotoxicity and vestibulotoxicity (Miller 1985). Estimates of the incidence of hearing loss after aminoglycoside

Editors: Guy P. Richardson and Christine Petit

Additional Perspectives on Function and Dysfunction of the Cochlea available at www.perspectivesinmedicine.org

Copyright (C) 2019 Cold Spring Harbor Laboratory Press; all rights reserved; doi: 10.1101/cshperspect.a033548

Cite this article as Cold Spring Harb Perspect Med 2019;9:a033548 
C.J. Kros and P.S. Steyger

Table 1. Major classes of therapeutic agents inducing permanent hearing loss (with examples and citations)

\begin{tabular}{|c|c|c|}
\hline Class & Examples & References \\
\hline Platinum-based therapeutics & Cisplatin, carboplatin, oxaliplatin & $\begin{array}{l}\text { Brock et al. 2012; Karasawa and } \\
\quad \text { Steyger } 2015\end{array}$ \\
\hline Aminoglycosides (AGs) & $\begin{array}{l}\text { Amikacin, gentamicin, kanamycin, } \\
\text { tobramycin }\end{array}$ & $\begin{array}{l}\text { Miller 1985; Schacht et al. 2012; } \\
\text { Jiang et al. } 2017\end{array}$ \\
\hline Peptide antibiotics & $\begin{array}{l}\text { Capreomycin, viomycin, } \\
\text { chloramphenicol }\end{array}$ & $\begin{array}{r}\text { Akbergenov et al. 2011; Kokong } \\
\text { et al. 2014; Arnold et al. } 2017\end{array}$ \\
\hline Polypeptide antibiotics & $\begin{array}{l}\text { Vancomycin (especially synergistically } \\
\text { with AGs) }\end{array}$ & $\begin{array}{l}\text { Brummett et al. 1990; Lestner et al. } \\
\text { 2016; Garinis et al. } 2018\end{array}$ \\
\hline Macrolides & Erythromycin & Miller 1985; Brummett 1993 \\
\hline Cyclodextrins (vehicle) & $\begin{array}{l}\text { Derivatives of cyclodextrins, for } \\
\text { Niemann-Pick syndrome type 1C }\end{array}$ & Crumling et al. 2017 \\
\hline Antimalarials & Chloroquine & $\begin{array}{l}\text { Bortoli and Santiago 2007; Kokong } \\
\text { et al. } 2014\end{array}$ \\
\hline $\begin{array}{l}\text { Loop diuretics (esp. synergistic with } \\
\text { AGs and cisplatin) }\end{array}$ & Furosemide, bumetanide & Rybak 1993 \\
\hline Nonopioid analgesics & Acetaminophen $=$ paracetamol & Yorgason et al. 2010 \\
\hline Antineoplastics & Vincristine(?) & Lugassy and Shapira 1996 \\
\hline
\end{tabular}

treatment vary widely, due to differing dosing regimens and sensitivities of audiological tests, yet may be as high as $20 \%-50 \%$ of recipients (Huth et al. 2015). Vestibulotoxicity can occur in up to $60 \%$ of treatment courses (van Hecke et al. 2017), and patients often self-report balance issues (and tinnitus) before any perceived cochleotoxicity. The lack of appropriate vestibulometric, compared to audiometric, testing facilities means that vestibulotoxicity remains woefully underreported. Furthermore, most audiometric diagnosis is within the $500-8000 \mathrm{~Hz}$ (conventional) testing range, underestimating the incidence of cochleotoxicity at higher frequencies where the onset of hearing loss typically occurs (Schacht et al. 2012). Aminoglycoside-induced ototoxicity is dose dependent in preclinical models and, likely, also in humans (Wu et al. 2001; Garinis et al. 2017a,b).

Aminoglycosides are polycationic molecules with molar masses between 300 and $600 \mathrm{~g} / \mathrm{mol}$, with a maximal cross-sectional diameter of $\sim 0.8 \mathrm{~nm}$ (van Netten and Kros 2007; Jiang et al. 2017). In bacteria, aminoglycosides bind to ribosomal RNA, causing misreading of messenger RNA (mRNA) and consequent accumulation of misfolded proteins that leads to cellular stress and bacterial lysis (Schacht et al. 2012). In mammals, aminoglycosides are selectively toxic to kidney proximal tubule cells, and to sensory hair cells of the inner ear. Drug-induced kidney damage is reversible if detected early and medication discontinued, as proximal tubule cells can regenerate, but this is not typically true for mammalian hair cells (Naughton 2008; Groves 2010; Kusaba et al. 2014; Lombardi et al. 2016). Since aminoglycosides target bacteria, they also readily disrupt mitochondria within cells, causing the release of proapoptotic factors and oxidative enzymes into the cytoplasm and the generation of free radicals (Warchol 2010; Huth et al. 2011; Esterberg et al. 2016).

Cisplatin degrades solid tumors, often with very high efficacy (e.g., $>90 \%$ cure rates for testicular carcinoma) (Cheng et al. 2018), yet the incidence of cochleotoxicity is very high with hearing loss in almost all treated patients (Callejo et al. 2015; Paken et al. 2016). As for aminoglycosides, onset of cisplatin-induced hearing loss typically occurs first in the extended highfrequency range before affecting sensitivity at conversational (lower) frequencies, as evaluated by distortion product otoacoustic emissions or conventional audiometry. Increasing the cumulative dose consistently leads to increasing risk of permanent hearing loss in humans (Brock 
Drug-Induced Ototoxicity and Otoprotection

et al. 2012; Garinis et al. 2017a). By contrast, there are few reports of vestibulotoxicity in patients treated with cisplatin, despite dose-dependent loss of vestibular hair cells and vestibular function in animals (Callejo et al. 2017), perhaps due to limitations in human vestibular testing protocols (Prayuenyong et al. 2018). Cisplatin is smaller than the aminoglycosides, with a molar mass of $300 \mathrm{~g} / \mathrm{mol}$ and a molecular "diameter" of $\sim 0.5 \mathrm{~nm}$. Cisplatin itself is not charged but the molecule is unstable and one or both of the $\mathrm{Cl}^{-}$ions can be replaced by $\mathrm{H}_{2} \mathrm{O}$ (aquation), resulting in monovalent or divalent cations. This reaction is favored when $\mathrm{Cl}^{-}$concentrations are low, as in the cytosol. Cisplatin can enter cells by passive diffusion, and via a variety of transporters, the most prominent of which are copper transporter CTR1 and organic cation transporter OCT2 (Waissbluth and Daniel 2013). Aquated cisplatin binds to nuclear DNA forming adducts that prevent transcription and replication, ultimately resulting in apoptosis, the basis of its cytotoxic antitumor activity, particularly in proliferating cancer cells that are poor at repairing DNA damage (Siddik 2003). Like aminoglycosides, cisplatin can also induce nephrotoxicity and ototoxicity, with neurotoxicity an additional outcome (Dzagnidze et al. 2007). These side effects are also likely due to the generation of toxic levels of reactive oxygen species that leads to apoptosis (Hazlitt et al. 2018a).

As aminoglycosides and cisplatin are typically infused parenterally in a hospital setting (aminoglycosides are also administered via middle ear [intratympanic] injections clinically), opportunities exist for coadministering therapeutics to prevent or reduce ototoxic side effects. Yet, despite much experimentation, there are no drugs that have been licensed for use in patients to prevent ototoxicity. This review discusses recent insights into how aminoglycosides and cisplatin damage sensory cells that respond to sound and motion. The intracellular mechanisms that lead to ototoxicity are also briefly discussed (with more detail in Schacht et al. 2012; Karasawa and Steyger 2015; Jiang et al. 2017). We end by considering how emerging insights can promote development of novel otoprotective therapies.

\section{TRAFFICKING OF CLINICAL OTOTOXINS INTO THE INNER EAR}

Ototoxicity results from drugs (ototoxins) entering inner ear tissues to exert their cytotoxic effects. Ototoxins must first cross the bloodlabyrinth barrier (BLB) that separates the bloodstream from inner ear tissues and fluids, predominantly the endolymph and perilymph (Fig. 1). The BLB is a specialized structure composed of tight junction-coupled inner ear endothelial cells that prevents macromolecules and blood cells from entering cochlear tissues via passive, paracellular extravasation from capillaries. Perilymph has an ionic composition similar to other extracellular fluids (high $\mathrm{Na}^{+}$, low $\mathrm{K}^{+}$, and millimolar $\mathrm{Ca}^{2+}$ ). In contrast, the endolymph has a high $\mathrm{K}^{+}$concentration, low $\mathrm{Na}^{+}$ and $\sim 20 \mathrm{nM} \mathrm{Ca}^{2+}$, as well as a positive endolymphatic potential (EP) of $\sim+80 \mathrm{mV}$ in the cochlea (but not in the vestibule). The composition of the endolymph is actively maintained by cells within the adjacent stria vascularis in the cochlea, and by dark cells in the vestibule (Wangemann 2006). Earlier cochlear studies reported higher aminoglycoside levels in perilymph than in the endolymph, suggesting that aminoglycosides in perilymph were the primary source of toxicity to hair cells (Tran Ba Huy et al. 1986). Although aminoglycosides enter perilymph following systemic administration, they do not readily enter hair cells via this route $(\mathrm{Li}$ and Steyger 2011). Experiments using fluorescently labeled gentamicin (gentamicin-Texas Red [GTTR]) revealed that systemically administered GTTR was more efficiently taken up by hair cells than GTTR perfused into the scala tympani. When applied systemically, GTTR readily trafficked across the BLB into the stria vascularis, and cleared into the endolymph prior to entering hair cells.

Surprisingly, following middle ear administration, auditory afferent fibers ipsilaterally, and vestibular efferent fibers bilaterally, transport aminoglycosides from cochlear perilymph to the auditory brainstem, although it is not yet known whether this leads to functional consequences (Zhang et al. 2012). Cochlear uptake of aminoglycosides and ototoxicity are also strong- 
C.J. Kros and P.S. Steyger

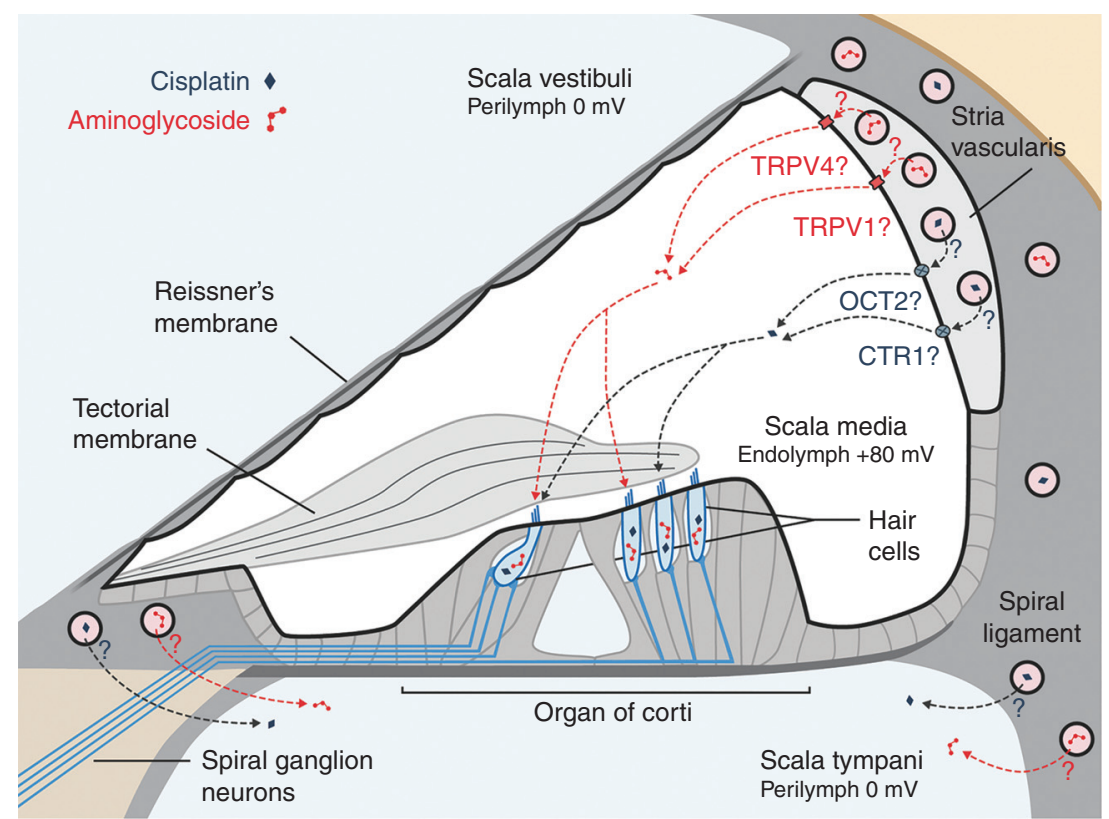

Figure 1. Main cochlear trafficking routes for systemic aminoglycosides and cisplatin. For both drugs, entry from the bloodstream into the cochlea occurs primarily from capillaries within the stria vascularis. From here, cisplatin enters the endolymph in the scala media, potentially through organic cation transporter 2 (OCT2) and copper transporter 1 (CTR1) transporters in the marginal cells. Aminoglycosides enter the endolymph through as-yetunidentified ion channels or transporters, although several candidates exist (e.g., transient receptor potential V1 [TRPV1] and TRPV4). From the endolymph, these ototoxins enter hair cells across their apical membranes.

ly increased during systemic inflammation that vasodilates capillaries in the stria vascularis (Koo et al. 2015). How exactly aminoglycosides enter the endolymph from the capillaries in the stria vascularis is currently not clear, but possibilities include ion channels, transporters, or transcytosis (Koo et al. 2015).

Like aminoglycosides, cisplatin and related compounds such as carboplatin and oxaliplatin have also been detected in perilymph following systemic administration, suggesting that these drugs may enter cochlear hair cells via their basolateral membranes (Hellberg et al. 2009, 2013). Yet, like aminoglycosides, various strands of evidence suggest that the stria vascularis-endolymph route is more likely. Iontophoretic application of cisplatin to the endolymphatic compartment of the guinea pig cochlea was more rapid and effective in reducing auditory nerve responses to sound than perfusion of perilymph with cisplatin-containing solution (McAlpine and Johnstone 1990). When loop diuretics were coadministered with cisplatin, hearing loss was exacerbated in guinea pigs (McAlpine and Johnstone 1990). In young cancer patients too, cotreatment with furosemide increased the risk of hearing loss (Clemens et al. 2016). The CTR1 and OCT2 transporters have been observed in stria vascularis but not in the spiral ligament, suggesting their possible involvement in cisplatin transport across the BLB into the endolymph (Ciarimboli et al. 2010; More et al. 2010; Waissbluth and Daniel 2013). Measurement of platinum levels in cisplatin-treated mice or patients revealed consistently higher levels in the stria vascularis that were retained for months to years, especially in the basal, highfrequency region (Breglio et al. 2017). The EP of cisplatin-treated mice dropped by up to $30 \mathrm{mV}$ during and after cisplatin treatment (Breglio et al. 2017). The entry of aminoglycosides and cisplatin into the vestibular endolymph remains 
incompletely understood, and likely involves the dark cells (the vestibular equivalent of the stria vascularis) and/or the transitional cells surrounding vestibular sensory epithelia (Liu et al. 2015a).

\section{ENTRY OF CLINICAL OTOTOXINS INTO HAIR CELLS}

To cause hair-cell death, the ototoxic drugs must first enter hair cells, or, alternatively, disrupt cochlear homeostasis. Aminoglycosides readily enter hair cells (Fig. 2) via stereociliary mechanoelectrical transduction (MET) channels that

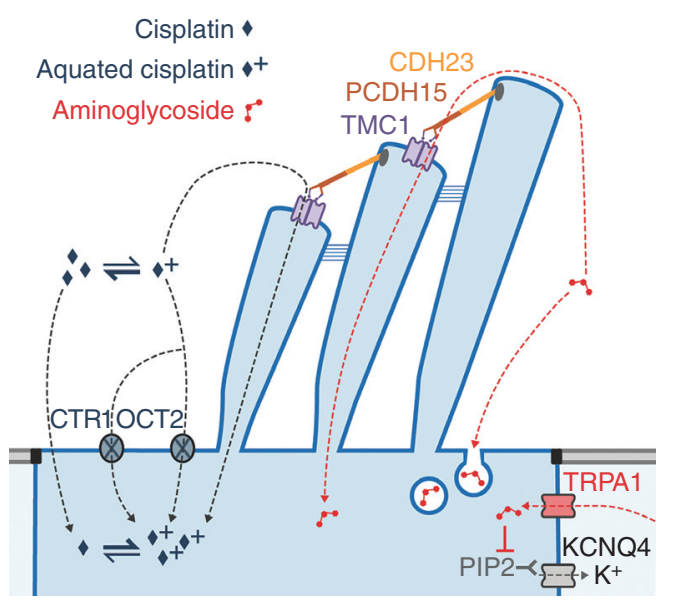

Figure 2. Aminoglycoside and cisplatin entry into hair cells from the endolymph. Both drugs preferentially enter hair cells across their apical membranes. Aminoglycosides predominantly enter hair cells via the MET channel complex, consisting of two transmembrane channel-like protein subunits (purple), each with a permeation pore. The MET channels are gated by movement of the stereocilia, mediated by tip links formed of CDH23 (orange) and PCDH15 (brown). Other minor routes include apical endocytosis, and basolateral TRPA1 channels. Intracellular aminoglycosides sequester $\mathrm{PIP}_{2}$, closing KCNQ4 potassium channels in the basolateral membrane. Cisplatin has multiple potential entry routes, for which the relative importance has not been established. Uptake of cisplatin, most likely in the aquated form, may occur via CTR1 and OCT2 transport proteins or through the MET channel pore. In its neutral form, cisplatin can permeate directly through cell membranes. open and close in response to sound or acceleration (Marcotti et al. 2005; Alharazneh et al. 2011; Vu et al. 2013), although other routes exist as well (e.g., endocytosis) (Hashino et al. 2000). The MET channels are large, nonselective cation channels with a relatively high permeability but low conductance for $\mathrm{Ca}^{2+}$ ions (Fettiplace and Kim 2014). The concentration of $\mathrm{Ca}^{2+}$ in the endolymph is relatively low $(\sim 20 \mu \mathrm{M})$ compared to the normal extracellular $(\sim 1.25 \mathrm{~mm})$ environment; the endolymph is also unusual in being rich in $\mathrm{K}^{+}$and poor in $\mathrm{Na}^{+}$ions (Wangemann and Schacht 1996). Experiments with a variety of cations that block the MET channel suggest that the channel permeation pathway is asymmetrical, with a wide extracellular-facing vestibule and a narrower selectivity filter (van Netten and Kros 2007). The $\mathrm{Ca}^{2+}$ ions from the endolymph are believed to be concentrated by this vestibule, which may contain negatively charged residues, from where they are further attracted to other negatively charged residues within the selectivity filter, and can then move either into the hair cell where they drive adaptation (Fettiplace and Kim 2014), or back out into the endolymph without entering the hair cell.

Recent evidence points to the permeation pathway of the MET channel being formed by a dimer of TMC proteins (Fig. 2), with two pores, one for each 10-transmembrane-domain TMC molecule (Ballesteros et al. 2018; Barr-Gillespie 2018; Corey et al. 2018; Pan et al. 2018). The permeation pathway, inferred from mapping to the closely related TMEM16, which has been crystallized (Brunner et al. 2014), is understood to be formed by transmembrane domains 4-7. While the exact mapping of TM domains and loops is still tentative and different in detail between the Ballesteros and Pan studies, it is clear that there are several negatively charged amino acids in the pore region, as well as positive ones that could form the entry and exit barriers. The electrochemical driving force of the $+80 \mathrm{mV}$ EP strongly promotes entry into the hair cells, boosted by the -40 to $-70 \mathrm{mV}$ resting membrane potential of cochlear hair cells to produce an electrical gradient of $120-150 \mathrm{mV}$ across the apical membrane of the hair cell. The polycationic aminoglycosides appear to 
compete with the $\mathrm{Ca}^{2+}$ ions for binding inside the channel pore, and are therefore permeant blockers of the MET channels (Marcotti et al. 2005). The MET channel pore is unusually large, with a diameter at its narrowest part of at least 1.25-1.5 nm (Farris et al. 2004; Alharazneh et al. 2011), large enough to allow aminoglycosides and other large cations to enter the hair cell cytosol. The fluorescent GTTR has a molar mass of $\sim 1125 \mathrm{~g} / \mathrm{mol}$, substantially larger than native gentamicin, but can nevertheless rapidly enter hair cells via their hair bundles (Alharazneh et al. 2011). This rapid entry of aminoglycosides down a strong electrochemical gradient, calculated as $\sim 9000$ molecules/hair cell/second for dihydrostreptomycin (DHS) (Marcotti et al. 2005), likely accounts for the mostly undetectable levels of aminoglycosides in the endolymph (Tran Ba Huy et al. 1986). Once inside hair cells, aminoglycosides cannot exit via MET channels, as the intracellular side lacks a vestibule and has a high energy barrier for reentry from the cytosol (Marcotti et al. 2005; van Netten and Kros 2007). Aminoglycosides also indirectly, via depletion of intracellular $\mathrm{PIP}_{2}$, inhibit voltage-gated potassium channels responsible for repolarizing hair cells, leading to a sustained cellular depolarization, which likely contributes to hair cell death (Leitner et al. 2011).

Other pathways for entry of aminoglycosides into hair cells exist. These pathways are quantitatively less important than the MET channel route, yet they can become unmasked when the MET channels are nonfunctional. One pathway is endocytosis at the apical and synaptic poles of hair cells, although direct evidence for its involvement in cytotoxicity has not been found (Hashino et al. 2000; Alharazneh et al. 2011; Vu et al. 2013). There is stronger evidence for a contribution by TRP channels, a family of polymodal ion channels activated by a variety of physical and chemical stimuli (Nilius and Szallasi 2014). Like MET channels, they are nonselective cation channels with a substantial permeability for $\mathrm{Ca}^{2+}$ ions. TRPA1 is considered a chemosensor, activated by various pungent and irritant compounds released during inflammation, oxidative stress and tissue damage, as well as bacterial endotoxins (Nilius and Szallasi
2014). TRPA1 is expressed by inner (IHCs) and outer hair cells (OHCs), and is assumed to be present on the basolateral membranes of OHCs. In murine cochlear cultures pretreated with BAPTA to disable MET channels, activated TRPA1 channels facilitated the uptake of GTTR, implying entry through the TRPA1 channels (Stepanyan et al. 2011). In HEK 293 cells, TRPA1 is blocked by gentamicin with a half-blocking concentration (Nagata et al. 2005) similar to that of hair cell MET channels. The TRPA1 pore diameter can dilate upon activation from 1.1 to $1.4 \mathrm{~nm}$ (Karashima et al. 2010). This suggests that TRPA1 channels can be activated during cochlear stress (e.g., that caused by noise exposure), potentially increasing aminoglycoside entry into OHCs (Yamashita et al. 2004; Li et al. 2015). TRPV1 and TRPV4 are additional candidate aminoglycoside-permeant channels, and both are expressed in the stria vascularis and the hair cells (Zheng et al. 2003; Myrdal and Steyger 2005; Karasawa et al. 2008).

Uptake of cisplatin by hair cells is less clear. Like the stria vascularis, cochlear hair cells express CTR1 and OCT2 (Ciarimboli et al. 2010; More et al. 2010; Waissbluth and Daniel 2013). If cisplatin predominantly enters hair cells via endolymph, these transporters would need to be present at the apical surface of the hair cells. Although the localization of CTR1 in hair cells is not clear (More et al. 2010), OCT2 labeling was found at the apical surface of the OHCs, and throughout the IHCs (Ciarimboli et al. 2010). Reduced cochleotoxicity occurs following systemic cisplatin administration in OCT1/2 double knockout mice, or when cimetidine, an OCT blocker, is administered contemporaneously with cisplatin (Ciarimboli et al. 2010). Intratympanic administration of copper sulfate (a primary substrate of CTR1) can also ameliorate cisplatin-induced cochleotoxicity, as judged by auditory brainstem response (ABR) threshold shifts (More et al. 2010). Cisplatin-induced cochleotoxicity may also be partially because of the loss of cochlear homeostasis, as well as hair-cell damage (Laurell et al. 2007), and the disruption of cochlear homeostasis can also indirectly affect hair-cell survival (Liu et al. 2016). 
It is not known whether mammalian vestibular hair cells express either of these transporters. Since the size of cisplatin $(\sim 0.5 \mathrm{~nm})$ is much smaller than the MET channel pore, it is conceivable that the mono- and/or biaquated forms of cisplatin could be permeant blockers of the MET channel, like the aminoglycosides. High doses of cisplatin, near the solubility limit in aqueous solution, block MET currents of chick cochlear hair cells, with a half-blocking concentration of about $1.5 \mathrm{~mm}$ (Kimitsuki et al. 1993, 1994) and a Hill coefficient of 2 , indicating that two molecules block the channel cooperatively. Voltage dependence was not investigated, so it is not clear whether block was permeant. Zebrafish neuromast hair cells with functional MET channels are killed by cisplatin, and zebrafish hair cells do not express CTR1 or OCT2 (Thomas et al. 2013). It is not yet known whether cisplatin blocks mammalian MET channels.

\section{MECHANISMS OF OTOTOXICITY}

Ototoxicity can be multifactorial, inducing damage to sensory hair cells or nonsensory cells with homeostatic functions in the inner ear that directly modulate hair cell function (e.g., in the stria vascularis). Ototoxicity can also occur in the neural pathway between the peripheral inner ear and the cortex of the brain, disrupting auditory and vestibular perception. Here we describe mostly peripheral mechanisms of ototoxicity that are better (but still incompletely) characterized.

Aminoglycosides in the perilymph can block the efferent synapses at the base of OHCs, disrupting the medial olivocochlear reflex that appears to protect auditory hair cells from exposure to loud sounds (Avan et al. 1996; Blanchet et al. 2000). Once aminoglycosides enter hair cells from the endolymph, they can also degrade the presynaptic ribbons prior to hair cell death (Liu et al. 2013; Oishi et al. 2015). This phenomenon could contribute to auditory dysfunction in cochlear regions with a high percentage of surviving hair cells (Nicol et al. 1992; Koo et al. 2015). Although the spontaneous repair of presynaptic ribbons in IHCs following lowdose gentamicin-induced cochleotoxicity has been reported, further characterization of this effect is needed (Liu et al. 2015b).

Within cells, aminoglycosides bind to numerous proteins suggestive of multiple mechanisms by which these drugs can induce hair cell death (Karasawa et al. 2011; Jiang et al. 2017). These include endoplasmic reticulum stress and disruption of mitochondrial integrity causing the generation of toxic reactive oxygen species that lead to cell death, particularly in hair cells (Oishi et al. 2015; Esterberg et al. 2016). Selected mitochondrial mutations (predominantly $\mathrm{A} 1555 \mathrm{G}$ ) in ribosomal RNA result in a higher binding affinity for aminoglycosides and can cause mistranslation of mRNA during protein synthesis resulting in cell death (Hobbie et al. 2008; Qian and Guan 2009; Matt et al. 2012).

Cisplatin-induced cytotoxicity is typically due to cisplatin binding to nuclear DNA, and downstream signaling resulting in apoptosis, particularly in proliferating cells (Eastman 1999). Hair cells are, however, postmitotic and do not proliferate. Many studies also report disruption of intracellular pathways and cisplatin binding to various proteins that may also contribute to cellular dysregulation and cell death (Gibson 2009; Karasawa et al. 2013). In cochlear cells, NADPH oxidase 3 (NOX3), is a major source of reactive oxygen species, and is highly expressed in the organ of Corti and spiral ganglion (Bánfi et al. 2004; Mukherjea et al. 2006). Cisplatin activates the transcription factor, signal transducer and activator of transcription 1 (STAT1) to trigger the TRPV1 and NOX3 signaling pathways that lead to cell death and hearing loss (Mukherjea et al. 2008, 2011).

In the avian papilla, hair cells lost due to ototoxicity or noise trauma can be regenerated by mitotic or nonmitotic (cellular transdifferentiation) mechanisms initiated by supporting cells (Girod et al. 1989, 1991; Tucci and Rubel 1990; Cotanche et al. 1994; Janas et al. 1995; Adler et al. 1997). Intriguingly, however, when the avian papilla is exposed to cisplatin, hair-cell regeneration is exceedingly low, suggesting that cisplatin-induced damage of supporting cells prevents mitotic and nonmitotic mechanisms of restoring hair-cell populations (Slattery and 
Warchol 2010). Cisplatin also damages supporting cells in the mammalian vestibular system (utricle), and blocks the proliferation of resident stem cells in the utricle, reducing the potential to regenerate hair cells (Slattery et al. 2014). Inflammation potentiates cisplatin-induced ototoxicity, as do loop diuretics (McAlpine and Johnstone 1990; Oh et al. 2011; Clemens et al. 2016).

Cisplatin also damages the stria vascularis, diminishing the generation of the endolymphatic potential essential for optimal auditory performance, and the spiral ganglion neurons (Campbell et al. 1999; Hamers et al. 2003; Sluyter et al. 2003; van Ruijven et al. 2005; Thomas et al. 2006; Laurell et al. 2007; Guthrie et al. 2008), suggesting that hearing loss due to cisplatin is multifactorial. Cisplatin also damages murine auditory cortical neurons in vitro, and rat hippocampal neural networks involved in memory in vivo (Gopal et al. 2012; Hinduja et al. 2015).

\section{OTOPROTECTION}

\section{Strategies for Otoprotection}

Blocking the production and/or effects of free radicals and proapoptotic factors have been intensely investigated to prevent aminoglycoside- and cisplatin-induced ototoxicity, and hold some promise for therapeutic intervention (Kalinec 2005; Sha et al. 2006; Chen et al. 2007; Huth et al. 2011; Brock et al. 2012). Alternative, potentially more specific, otoprotective strategies include blocking ototoxin entry into the cochlear fluids and hair cells, thus preventing these ototoxic compounds from reaching their targets in the first place. Modification of the drugs themselves to retain their desired efficacy while ameliorating ototoxicity is another approach that has been investigated. Below, we briefly discuss these and other strategies.

\section{Modulating Drug Transport across the BLB}

The surest way to avoid ototoxicity is to prevent entry of ototoxic agents into the inner ear. Analogous to the blood-brain barrier $(\mathrm{BBB})$, the inner ear is substantially protected by the BLB. The main blood supply to the inner ear is via the spiral modiolar artery radiating arterioles to the spiral limbus, spiral ligament (perilymph), and stria vascularis (endolymph). The permeability of the BLB can be modulated by drugs like loop diuretics (Taylor et al. 2008), and in experimental models of systemic inflammation that mimic serious infection, to potentiate both aminoglycoside- and cisplatin-induced cochleotoxicity ( $\mathrm{Oh}$ et al. 2011; Koo et al. 2015). On the other hand, a detailed understanding of the relation between the physicochemical properties of drugs and BLB permeability is lacking at present. Increased understanding of the BLB will optimize trafficking of otoprotective compounds across the BLB into the inner ear for increased efficacy.

\section{Blocking the MET Channel}

Designing competitive blockers to prevent ototoxins entering hair cells via their MET channels is an attractive strategy, especially for aminoglycosides, for which this is the major entry route (Gale et al. 2001; Marcotti et al. 2005; Alharazneh et al. 2011). Cisplatin, by contrast, likely has multiple entry mechanisms into cells, including hair cells (Waissbluth and Daniel 2013). Ideally, a protective compound would be a nonpermeant, reversible blocker that could be coadministered with the ototoxin, either systemically or intratympanically. The arrow poison, D-tubocurarine, is a nonpermeant MET channel blocker in turtle auditory hair cells (Farris et al. 2004), and permeates MET channels in murine $\mathrm{OHCs}$ in vitro at an order of magnitude slower than the aminoglycoside DHS (Kirkwood et al. 2017). Further optimization of this compound, which protects hair cells in zebrafish and cochlear cultures, for otoprotection in vivo via intratympanic injection would involve eliminating permeation through the MET channel and reducing its anticholinergic action to avoid blocking the middle ear reflex. Whereas this block might cause a transient loss of hearing and remodeling of the stereociliary bundle, the latter effect is, at least in vitro, also reversible (VelezOrtega et al. 2017). 
Drug-Induced Ototoxicity and Otoprotection

\section{Modifying Ototoxin Structure to Reduce Ototoxicity}

This strategy has been applied to both aminoglycosides and cisplatin. Although the clinically approved aminoglycosides are reported to be either more cochleotoxic or more vestibulotoxic in the clinic, all nevertheless still cause damage to both cochlear and vestibular hair cells to varying degrees (Miller 1985). Apramycin, an aminoglycoside currently licensed for veterinary use, combines potent and wide-spectrum antimicrobial activity with relatively little ototoxicity, probably because it has very little activity against mitochondrial ribosomes (Matt et al. 2012). This feature could be explored as a basis for the rational design of novel, less ototoxic aminoglycosides that still retain bactericidal efficacy. Another promising approach optimized an existing aminoglycoside, sisomicin (similar to gentamicin), by reducing the number of positive charges to reduce uptake by hair cells. One compound that was designed (N1MS) had a lower affinity for the MET channel than the parent compound and preserved hearing in mice, but at the expense of a narrowed spectrum of antibacterial activity (Huth et al. 2015). Various cisplatin congeners have been designed with the aim of reducing ototoxicity (e.g., carboplatin and oxaliplatin). Unfortunately, lower ototoxicity tends to come at the cost of reduced antitumor efficacy (Brock et al. 2012).

\section{Drug Discovery and Optimization Using Zebrafish}

A candidate otoprotective compound (PROTO1) was originally discovered using a screen based on larval zebrafish lateral-line neuromasts (Owens et al. 2008). Rational optimization of PROTO-1 identified a derivative, ORC-13661 (Chowdhury et al. 2018), that was recently awarded investigational new drug (IND) status by the United States Food and Drug Administration (FDA), providing direction for others to follow. The primary outcome measure was the concentration of a compound required to protect neuromast hair cells in the face of challenge by the aminoglycoside neomycin (Chowdhury et al. 2018). The dose-response relationships for numerous compounds in hair-cell survival assays can be determined within days using zebrafish, rather than over many months, with a relatively low degree of variability. However, lead compounds from such assays do not always provide otoprotection in mammals in vivo (Majumder et al. 2017), though the aforementioned ORC-13661 is very promising.

A similar approach by Kenyon et al. (2017) using zebrafish identified six hits from a screen of 160 known ion-channel modulators for permeant blockers of murine hair cell MET channels. Whether MET channel block is the primary otoprotective mechanism of these candidates remains to be verified, as several of these compounds can also affect other ion channels (e.g., NMDA receptors). These compounds, plus two others that did not interact with the MET channel, protected OHCs from gentamicin-induced ototoxicity in vitro, and were not themselves cytotoxic to OHCs at high concentrations.

\section{Drug Discovery and Optimization Using Cell Lines}

An alternative strategy for large-scale screening for candidate otoprotective compounds is to use immortalized cell lines derived from the mouse cochlea, such as the widely used HEI-OC1 (Kalinec et al. 2003). Unlike zebrafish larval neuromast hair-cell screens, it is unlikely that such screens will yield compounds that interact with the MET channels, as HEI-OC1 cells do not express functional MET channels. However, other otoprotective mechanisms that are directly relevant to the mammalian inner ear may be found instead. CDK2 (cyclin-dependent kinase 2) was identified as a target for protection from cisplatin ototoxicity in a screen of over 4000 small molecules in the HEI-OC1 cell line (Teitz et al. 2018). CDK2 inhibition reduces reactive oxygen species production from mitochondria in response to cisplatin, and to date three such inhibitors have been identified as candidate otoprotective compounds (Hazlitt et al. 2018b; Teitz et al. 2018). 


\section{Targeting Intracellular Cell-Death Pathways}

Targeting intracellular signaling pathways that lead to apoptotic hair cell death can be otoprotective in preclinical studies. Inhibiting the JNK pathway protected mice from aminoglycosideand noise-induced hearing loss (Wang et al. 2003), but not from cisplatin-induced hearing loss (Wang et al. 2004). Inhibition of cell deathassociated caspases (Wang et al. 2004) and p53 (Benkafadar et al. 2017) did, however, protect mice from cisplatin ototoxicity. The p53 inhibitor PFT- $\alpha$ protected hearing when administered intratympanically, or systemically, without interfering with the tumoritoxic efficacy of cisplatin.

Antioxidants like $\mathrm{N}$-acetylcysteine and D-methionine also reduce aminoglycoside-induced cochleotoxicity in preclinical models (Somdas et al. 2015; Campbell et al. 2016; Turan et al. 2017), supporting the notion that drug-induced generation of reactive oxygen species leads to ototoxicity. D-methionine can also reduce cisplatin-induced disruption of central neural pathways (Gopal et al. 2012; Hinduja et al. 2015). Some antioxidants show otoprotection against both aminoglycosides and cisplatin (Lorito et al. 2011; Tate et al. 2017).

Aminoglycoside treatment also leads to hypoacetylation of nuclear histones, reducing transcription factor binding to DNA and decreasing gene expression (Chen et al. 2009). Histone deacetylases (HDACs) remove histone acetylation, and specific inhibitors of HDACs are protective in cochlear explants (Chen et al. 2009), yet often are not otoprotective in vivo (Yang et al. 2017). This dissociation between in vitro and in vivo studies demonstrates that the efficacy of candidate otoprotective agents must be verified in vivo.

Inducible expression of activation of heat shock proteins (HSPs) by supporting cells can promote hair-cell survival against ototoxicity (Taleb et al. 2008; May et al. 2013). Induced expression of cochlear HSPs can be caused by exposure to sound levels sufficient to elicit temporary threshold shifts. This transiently stresses the cochlea, yet significantly reduces the degree of both aminoglycoside and cisplatin-induced ototoxicity (Roy et al. 2013).

\section{Novel Otoprotective Strategies}

Recently, several novel otoprotective strategies have been reported. Steroids are otoprotective, yet may also decrease the tumoritoxicity of platin-based drugs when administered systemically, or have safety issues when dosed chronically (reviewed by Ramaswamy et al. 2017). Alternatively, locally delivered steroids can undergo rapid clearance from inner ear tissues (Salt and Plontke 2009). To circumvent these issues, Ramaswamy et al. (2017) injected prednisolone-loaded magnetic nanoparticles intratympanically and used a contralateral magnet to pull the nananoparticles into the inner ear from the middle ear space. This approach reduced cisplatin-induced hearing loss in the high-frequency (basal) region of the cochlea.

A cell-penetrating peptide vaccine, GV1001, was recently shown to alleviate inflammatory responses, oxidative stress, and apoptosis, as reviewed by Kim et al. (2018). Significantly reduced hearing loss (and OHC loss) occurred when the peptide was parenterally administered contemporaneously with (or 1 or 3 days following) a single combined dose of aminoglycoside and furosemide that induces catastrophic hearing loss (Kim et al. 2018). Validating the mechanism of action will be of great interest given the spatiotemporal separation between potent ototoxin dosing and administration of the otoprotective peptide vaccine.

Aqueous and gaseous hydrogen $\left(\mathrm{H}_{2}\right)$ have shown potential in preventing ischemia in several animal models of ototoxicity and nephrotoxicity, presumptively by reducing oxidative stress (reviewed by Fransson et al. 2017). Gaseous $\mathrm{H}_{2}$ is safe at levels $<4 \%$ of atmospheric air, and does not induce adverse reactions in humans (Huang et al. 2011). The BLB, or other cochlear barriers, are not thought to pose a significant obstacle to the penetration of dissolved gases like $\mathrm{H}_{2}, \mathrm{CO}_{2}$, or $\mathrm{O}_{2}$, among others. Fransson et al. (2017) found that $\mathrm{H}_{2}$ inhalation ( $2 \%$ for $60 \mathrm{~min}$ ) abrogated cisplatin-induced loss of CTR1 or synaptophysin, and loss of OHCs in guinea pigs. Crucially, inhaled $\mathrm{H}_{2}$ significantly reduced cisplatin-induced hearing loss (Fransson et al. 2017). 


\section{CHALLENGES TO PREVENTING OTOTOXICITY}

Several challenges to preventing ototoxicity exist. These are (1) insufficient understanding of the mechanisms of ototoxicity for individual ototoxins, (2) knowing which otoprotective strategy is best for individual ototoxins, and (3) translating this knowledge into efficacious therapeutic interventions. Each are briefly discussed.

\section{Mechanisms of Ototoxicity}

Individual ototoxins have different (and often multiple) mechanisms of cytotoxicity that can vary between cell type, cell status, and local environment. This is typified by cisplatin, which is preferentially cytotoxic in proliferating cells, yet remains toxic to terminally differentiated cochlear hair cells no longer undergoing cell division. In the cochlea, cisplatin's cytotoxicity appears to primarily derive from its interference with cellular redox status and from biasing cellular inflammatory responses toward apoptosis (Ross et al. 2009; Ghosh et al. 2018). In addition, supporting cells in the avian basilar papilla appear to (initially) survive exposure to cisplatin, yet cannot retain adequate proliferative capacity to initiate hair-cell regeneration typically seen after noise or aminoglycoside exposure (Cotanche et al. 1994; Woolley et al. 2001; Slattery and Warchol 2010; Slattery et al. 2014). How other ototoxins affect cochlear cell types remain to be determined. Aminoglycosides bind to large numbers of intracellular proteins, and it is not yet clear which aminoglycoside-binding proteins are themselves crucial for cell survival, and which can sequester the drug to promote cellular survival (Karasawa et al. 2010, 2011). More importantly, unlike hair cells and renal proximal tubule cells, most cells can clear aminoglycosides from their cytosol, yet the mechanisms by which this occurs remain unknown (Dai et al. 2006).

\section{Mechanisms of Otoprotection}

Mechanisms of otoprotection are often uncertain. For example, aspirin (salicyclate) is considered to be an antioxidant that can sequester free oxygen radicals to reduce the degree and extent of OHC loss (i.e., ototoxicity) (Sha and Schacht 1999; Chen et al. 2007). However, loss of OHCs via apoptosis is dependent on the translocation of cytoplasmic NF- $\kappa \mathrm{B}$ to the nucleus, yet this translocation of NF- $\mathrm{KB}$ is inhibited by aspirin in other cell systems (Ramakrishnan and Jusko 2001; Jiang et al. 2005), suggesting that aspirin has additional mechanisms of otoprotection besides being an antioxidant. Thus, accurate interpretation of data is dependent on understanding the full range of activities of candidate otoprotectants to avoid erroneous mechanistic assumptions and conclusions. The discovery of novel otoprotectants can reveal new mechanisms of ototoxicity. For example, the unexpected efficacy of CDK2 inhibitors in protecting hair cells suggest that cell cycle kinases can regulate drug-induced apoptosis (Hazlitt et al. 2018b; Teitz et al. 2018). Thus, the role of this signaling pathway in the cytotoxicity of postmitotic hair cells needs further characterization. As mechanisms of otoprotection become more fully understood, individual candidate otoprotectants could be used for multiple ototoxins with similar mechanisms of action. The phenomenon of increased drug uptake by the cochlea during immunogenic inflammation (i.e., by bacterial or viral infections) may also promote an increased uptake of otoprotectants, akin to that for the inadvertent increased uptake of aminoglycosides that nefariously enhances cochleotoxicity (Koo et al. 2015).

Another primary consideration for successful translation of a candidate otoprotectant into clinical practice is that the protective efficacy of the candidate otoprotectant must not protect bacteria or tumors from the intended bactericidal effects of aminoglycosides or tumoritoxicity of platin-based drugs. This consideration has delayed the use of antioxidant-based otoprotective candidates, like sodium thiosulfate, developed to prevent cisplatin-induced ototoxicity (Freyer et al. 2017; Brock et al. 2018), and remains the subject of intense debate for antioxidants in general. It is for this reason that in vivo preclinical studies must closely mimic the medical setting in which these compounds will be used. This includes chronic dosing, inducing 
live infection and/or subsequent inflammatory response models for aminoglycosides (Koo et al. 2015), and xenografting appropriate tumor models combined with subsequent inflammatory models (where appropriate) for platin-based drugs like cisplatin.

\section{Translation into Clinical Practice}

Translating preclinical mechanisms of otoprotection into clinical practice remains challenging on numerous levels. Unless the primary site of otoprotection is at the BLB, candidate otoprotectants must traverse the BLB at therapeutic levels. If systemic administration is not practical or safe, local delivery via intratympanic administration may be a viable alternative, providing the candidate otoprotectant remains efficacious when primarily delivered to perilymph. Other mechanisms of preventing ototoxicity include antibiotic stewardship to reduce aminoglycoside dosing and the risk of bacterial resistance to aminoglycosides (Pitiriga et al. 2017). Additional otoprotective strategies include the development of improved diagnosis for sepsis using PCR detection of microbial DNA sequences (Trung et al. 2016) to reduce the incidence of prophylactic aminoglycoside dosing, as well as genetic screening for mutations known to enhance susceptibility to aminoglycoside- or cisplatin-induced ototoxicity (Ross et al. 2009; Jing et al. 2015).

\section{CONCLUSIONS}

Over the last 70 years and since the discovery of aminoglycosides and cisplatin, considerable information has been acquired about the mechanisms of ototoxicity, underpinning novel strategies of cytoprotection specific for the inner ear. This foundation has poised the field for an exponential growth of new knowledge regarding mechanisms of ototoxicity, and the discovery of candidate otoprotective compounds. This growth phase provides unprecedented opportunities for academia and biotechnology companies to collaborate on multiple levels, from genetics and epidemiology to drug discovery, toward preventing the devastating and debilitating consequences of drug-induced hearing loss.

\section{ACKNOWLEDGMENTS}

This work was supported by MRC Programme Grant No. MR/K005561/1 (C.J.K.), and by NIHNIDCD Grant No. R01 DC004555 (P.S.S.). The illustrations were drafted by Karen Thiebes, Simplified Science Publishing. Funding agencies had no role in the preparation of this manuscript, or decision to publish.

\section{REFERENCES}

${ }^{*}$ Reference is also in this collection.

Adler HJ, Komeda M, Raphael Y. 1997. Further evidence for supporting cell conversion in the damaged avian basilar papilla. Int J Dev Neurosci 15: 375-385. doi:10.1016/ S0736-5748(96)00098-6

Akbergenov R, Shcherbakov D, Matt T, Duscha S, Meyer M, Wilson DN, Böttger EC. 2011. Molecular basis for the selectivity of antituberculosis compounds capreomycin and viomycin. Antimicrob Agents Chemother 55: 47124717. doi:10.1128/AAC.00628-11

Alharazneh A, Luk L, Huth M, Monfared A, Steyger PS, Cheng AG, Ricci AJ. 2011. Functional hair cell mechanotransducer channels are required for aminoglycoside ototoxicity. PLoS ONE 6: e22347. doi:10.1371/journal. pone.0022347

Arnold A, Cooke GS, Kon OM, Dedicoat M, Lipman M, Loyse A, Chis Ster I, Harrison TS. 2017. Adverse effects and choice between the injectable agents amikacin and capreomycin in multidrug-resistant tuberculosis. Antimicrob Agents Chemother 61: e02586. doi:10.1128/ AAC.02586-16

Avan P, Erre JP, da Costa DL, Aran JM, Popelár J. 1996. The efferent-mediated suppression of otoacoustic emissions in awake guinea pigs and its reversible blockage by gentamicin. Exp Brain Res 109: 9-16. doi:10.1007/ BF00228621

Ballesteros A, Fenollar-Ferrer C, Swartz KJ. 2018. Structural relationship between the putative hair cell mechanotransduction channel TMC1 and TMEM16 proteins. eLife 7: e38433. doi:10.7554/eLife.38433

Bánfi B, Malgrange B, Knisz J, Steger K, Dubois-Dauphin M, Krause KH. 2004. NOX3, a superoxide-generating NADPH oxidase of the inner ear. J Biol Chem 279: 46065-46072. doi:10.1074/jbc.M403046200

Barr-Gillespie PG. 2018. Honing in on TMC as the hair cell's transduction channel. Neuron 99: 628-629. doi:10.1016/j. neuron.2018.08.013

Benkafadar N, Menardo J, Bourien J, Nouvian R, François F, Decaudin D, Maiorano D, Puel JL, Wang J. 2017. Reversible p53 inhibition prevents cisplatin ototoxicity without blocking chemotherapeutic efficacy. EMBO Mol Med 9: 7-26. doi:10.15252/emmm.201606230 
Blanchet C, Eróstegui C, Sugasawa M, Dulon D. 2000. Gentamicin blocks ACh-evoked $\mathrm{K}^{+}$current in guinea-pig outer hair cells by impairing $\mathrm{Ca}^{2+}$ entry at the cholinergic receptor. J Physiol 525(Pt 3): 641-654. doi:10.1111/ j.1469-7793.2000.t01-1-00641.x

Bortoli R, Santiago M. 2007. Chloroquine ototoxicity. Clin Rheumatol 26: 1809-1810. doi:10.1007/s10067-007 0662-6

Breglio AM, Rusheen AE, Shide ED, Fernandez KA, Spielbauer KK, McLachlin KM, Hall MD, Amable L, Cunningham LL. 2017. Cisplatin is retained in the cochlea indefinitely following chemotherapy. Nat Commun 8: 1654 doi:10.1038/s41467-017-01837-1

Brock PR, Knight KR, Freyer DR, Campbell KC, Steyger PS, Blakley BW, Rassekh SR, Chang KW, Fligor BJ, Rajput K, et al. 2012. Platinum-induced ototoxicity in children: A consensus review on mechanisms, predisposition, and protection, including a new International Society of Pediatric Oncology Boston ototoxicity scale. J Clin Oncol 30: 2408-2417. doi:10.1200/JCO.2011.39.1110

Brock PR, Maibach R, Childs M, Rajput K, Roebuck D, Sullivan MJ, Laithier V, Ronghe M, Dall'Igna P, Hiyama E, et al. 2018. Sodium thiosulfate for protection from cisplatin-induced hearing loss. N Engl J Med 378: 2376 2385. doi:10.1056/NEJMoa1801109

Brummett RE. 1993. Ototoxic liability of erythromycin and analogues. Otolaryngol Clin North Am 26: 811-819.

Brummett RE, Fox KE, Jacobs F, Kempton JB, Stokes Z, Richmond AB. 1990. Augmented gentamicin ototoxicity induced by vancomycin in guinea pigs. Arch Otolaryngol Head Neck Surg 116: 61-64. doi:10.1001/archotol. 1990.01870010065019

Brunner JD, Lim NK, Schenck S, Duerst A, Dutzler R. 2014. X-ray structure of a calcium-activated TMEM16 lipid scramblase. Nature 516: 207-212. doi:10.1038/nature 13984

Callejo A, Sedó-Cabezón L, Juan ID, Llorens J. 2015. Cisplatin-induced ototoxicity: Effects, mechanisms and protection strategies. Toxics 3: 268-293. doi:10.3390/tox ics3030268

Callejo A, Durochat A, Bressieux S, Saleur A, Chabbert C, Domènech Juan I, Llorens J, Gaboyard-Niay S. 2017. Dose-dependent cochlear and vestibular toxicity of trans-tympanic cisplatin in the rat. Neurotoxicology 60: 1-9. doi:10.1016/j.neuro.2017.02.007

Campbell KC, Meech RP, Rybak LP, Hughes LF. 1999. D-Methionine protects against cisplatin damage to the stria vascularis. Hear Res 138: 13-28. doi:10.1016/ S0378-5955(99)00142-2

Campbell KC, Martin SM, Meech RP, Hargrove TL, Verhulst SJ, Fox DJ. 2016. D-methionine (D-met) significantly reduces kanamycin-induced ototoxicity in pigmented guinea pigs. Int J Audiol 55: 273-278. doi:10.3109/ 14992027.2016.1143980

Chen Y, Huang WG, Zha DJ, Qiu JH, Wang JL, Sha SH, Schacht J. 2007. Aspirin attenuates gentamicin ototoxicity: From the laboratory to the clinic. Hear Res 226: 178182. doi:10.1016/j.heares.2006.05.008

Chen FQ, Schacht J, Sha SH. 2009. Aminoglycoside-induced histone deacetylation and hair cell death in the mouse cochlea. J Neurochem 108: 1226-1236. doi:10.1111/ j.1471-4159.2009.05871.x
Drug-Induced Ototoxicity and Otoprotection

Cheng L, Albers P, Berney DM, Feldman DR, Daugaard G, Gilligan T, Looijenga LHJ. 2018. Testicular cancer. Nat Rev Dis Primers 4: 29. doi:10.1038/s41572-018-0029-0

Chowdhury S, Owens KN, Herr RJ, Jiang Q, Chen X, Johnson G, Groppi VE, Raible DW, Rubel EW, Simon JA. 2018. Phenotypic optimization of urea-thiophene carboxamides to yield potent, well tolerated, and orally active protective agents against aminoglycoside-induced hearing loss. J Med Chem 61: 84-97. doi:10.1021/acs.jmed chem.7b00932

Ciarimboli G, Deuster D, Knief A, Sperling M, Holtkamp M, Edemir B, Pavenstadt H, Lanvers-Kaminsky C, am Zehnhoff-Dinnesen A, Schinkel AH, et al. 2010. Organic cation transporter 2 mediates cisplatin-induced oto- and nephrotoxicity and is a target for protective interventions. Am J Pathol 176: 1169-1180. doi:10.2353/ajpath. 2010.090610

Clemens E, de Vries AC, Pluijm SF, Am Zehnhoff-Dinnesen A, Tissing WJ, Loonen JJ, van Dulmen-den Broeder E, Bresters D, Versluys B, Kremer LC, et al. 2016. Determinants of ototoxicity in 451 platinum-treated Dutch survivors of childhood cancer: A DCOG late-effects study. Eur J Cancer 69: 77-85. doi:10.1016/j.ejca.2016. 09.023

* Corey DP, Akyuz N, Holt JR. 2018. Function and dysfunction of TMC channels in inner ear hair cells. Cold Spring Harb Perspect Med doi:10.1101/cshperspect.a033506

Cotanche DA, Lee KH, Stone JS, Picard DA. 1994. Hair cell regeneration in the bird cochlea following noise damage or ototoxic drug damage. Anat Embryol (Berl) 189: 1-18. doi:10.1007/BF00193125

Crumling MA, King KA, Duncan RK. 2017. Cyclodextrins and iatrogenic hearing loss: New drugs with significant risk. Front Cell Neurosci 11: 355. doi:10.3389/fncel. 2017.00355

Dai CF, Mangiardi D, Cotanche DA, Steyger PS. 2006. Uptake of fluorescent gentamicin by vertebrate sensory cells in vivo. Hear Res 213: 64-78. doi:10.1016/j.heares. 2005.11.011

Dzagnidze A, Katsarava Z, Makhalova J, Liedert B, Yoon MS, Kaube H, Limmroth V, Thomale J. 2007. Repair capacity for platinum-DNA adducts determines the severity of cisplatin-induced peripheral neuropathy. J Neurosci 27: 9451-9457. doi:10.1523/jneurosci.0523-07.2007

Eastman A. 1999. The mechanism of action of cisplatin: From adducts to apoptosis. In Cisplatin: Chemistry and biochemistry of a leading anticancer drug (ed. Lippert B), pp. 111-134. Wiley, Zürich.

Escobar GJ, Li DK, Armstrong MA, Gardner MN, Folck BF, Verdi JE, Xiong B, Bergen R. 2000. Neonatal sepsis workups in infants $\geq 2000$ grams at birth: A populationbased study. Pediatrics 106: 256-263. doi:10.1542/peds. 106.2.256

Esterberg R, Linbo T, Pickett SB, Wu P, Ou HC, Rubel EW, Raible DW. 2016. Mitochondrial calcium uptake underlies ROS generation during aminoglycoside-induced hair cell death. J Clin Invest 126: 3556-3566. doi:10.1172/ JCI84939

Farris HE, LeBlanc CL, Goswami J, Ricci AJ. 2004. Probing the pore of the auditory hair cell mechanotransducer channel in turtle. J Physiol 558: 769-792. doi:10.1113/ jphysiol.2004.061267 
Fettiplace R, Kim KX. 2014. The physiology of mechanoelectrical transduction channels in hearing. Physiol Rev 94: 951-986. doi:10.1152/physrev.00038.2013

Fransson AE, Kisiel M, Pirttilä K, Pettersson C, Videhult Pierre P, Laurell GFE. 2017. Hydrogen inhalation protects against ototoxicity induced by intravenous cisplatin in the guinea pig. Front Cell Neurosci 11: 280. doi:10.3389/ fncel.2017.00280

Freyer DR, Chen L, Krailo MD, Knight K, Villaluna D, Bliss B, Pollock BH, Ramdas J, Lange B, Van Hoff D, et al. 2017. Effects of sodium thiosulfate versus observation on development of cisplatin-induced hearing loss in children with cancer (ACCL0431): A multicentre, randomised, controlled, open-label, phase 3 trial. Lancet Oncol 18: 6374. doi:10.1016/S1470-2045(16)30625-8

Gale JE, Marcotti W, Kennedy HJ, Kros CJ, Richardson GP. 2001. FM1-43 dye behaves as a permeant blocker of the hair-cell mechanotransducer channel. J Neurosci 21: 7013-7025. doi:10.1523/jneurosci.21-18-07013.2001

Garinis AC, Cross CP, Srikanth P, Carroll K, Feeney MP, Keefe DH, Hunter LL, Putterman DB, Cohen DM, Gold JA, et al. 2017a. The cumulative effects of intravenous antibiotic treatments on hearing in patients with cystic fibrosis. J Cyst Fibros 16: 401-409. doi:10.1016/j.jcf.2017. 01.006

Garinis AC, Liao S, Cross CP, Galati J, Middaugh JL, Mace JC, Wood AM, McEvoy L, Moneta L, Lubianski T, et al. 2017b. Effect of gentamicin and levels of ambient sound on hearing screening outcomes in the neonatal intensive care unit: A pilot study. Int J Pediatr Otorhinolaryngol 97: 42-50. doi:10.1016/j.ijporl.2017.03.025

Garinis AC, Kemph A, Tharpe AM, Weitkamp JH, McEvoy C, Steyger PS. 2018. Monitoring neonates for ototoxicity. Int J Audiol 57 (Suppl 4): S41-S48. doi:10.1080/1499 2027.2017.1339130

Ghosh S, Sheth S, Sheehan K, Mukherjea D, Dhukhwa A, Borse V, Rybak LP, Ramkumar V. 2018. The endocannabinoid/cannabinoid receptor 2 system protects against cisplatin-induced hearing loss. Front Cell Neurosci 12: 271. doi:10.3389/fncel.2018.00271

Gibson D. 2009. The mechanism of action of platinum anticancer agents-What do we really know about it? Dalton Trans 48: 10681-10689. doi:10.1039/b918871c

Girod DA, Duckert LG, Rubel EW. 1989. Possible precursors of regenerated hair cells in the avian cochlea following acoustic trauma. Hear Res 42: 175-194. doi:10.1016/ 0378-5955(89)90143-3

Girod DA, Tucci DL, Rubel EW. 1991. Anatomical correlates of functional recovery in the avian inner ear following aminoglycoside ototoxicity. Laryngoscope 101: 11391149. doi:10.1288/00005537-199111000-00001

Gopal KV, Wu C, Shrestha B, Campbell KC, Moore EJ, Gross GW. 2012. D-Methionine protects against cisplatin-induced neurotoxicity in cortical networks. Neurotoxicol Teratol 34: 495-504. doi:10.1016/j.ntt.2012.06.002

Groves AK. 2010. The challenge of hair cell regeneration. Exp Biol Med (Maywood) 235: 434-446. doi:10.1258/ebm. 2009.009281

Guthrie OW, Li-Korotky HS, Durrant JD, Balaban C. 2008. Cisplatin induces cytoplasmic to nuclear translocation of nucleotide excision repair factors among spiral ganglion neurons. Hear Res 239: 79-91. doi:10.1016/j.heares.2008. 01.013

Hamers FP, Wijbenga J, Wolters FL, Klis SF, Sluyter S, Smoorenburg GF. 2003. Cisplatin ototoxicity involves organ of Corti, stria vascularis and spiral ganglion: Modulation by $\alpha \mathrm{MSH}$ and ORG 2766. Audiol Neurotol 8: 305-315. doi:10.1159/000073515

Hashino E, Shero M, Salvi RJ. 2000. Lysosomal augmentation during aminoglycoside uptake in cochlear hair cells. Brain Res 887: 90-97. doi:10.1016/S0006-8993(00) 02971-1

Hazlitt RA, Min J, Zuo J. 2018a. Progress in the development of preventative drugs for cisplatin-induced hearing loss. $J$ Med Chem 61: 5512-5524. doi:10.1021/acs.jmed chem.7b01653

Hazlitt RA, Teitz T, Bonga JD, Fang J, Diao S, Iconaru LI, Yang L, Goktug AN, Currier DG, Chen T, et al. 2018b. Development of second-generation CDK2 inhibitors for the prevention of cisplatin-induced hearing loss. J Med Chem 61: 7700-7709. doi:10.1021/acs.jmedchem. $8 \mathrm{~b} 00669$

Hellberg V, Wallin I, Eriksson S, Hernlund E, Jerremalm E, Berndtsson M, Eksborg S, Arner ES, Shoshan M, Ehrsson $\mathrm{H}$, et al. 2009. Cisplatin and oxaliplatin toxicity: Importance of cochlear kinetics as a determinant for ototoxicity. J Natl Cancer Inst 101: 37-47. doi:10.1093/jnci/djn418

Hellberg V, Wallin I, Ehrsson H, Laurell G. 2013. Cochlear pharmacokinetics of cisplatin: An in vivo study in the guinea pig. Laryngoscope 123: 3172-3177. doi:10.1002/ lary. 24235

Hinduja S, Kraus KS, Manohar S, Salvi RJ. 2015. D-Methionine protects against cisplatin-induced neurotoxicity in the hippocampus of the adult rat. Neurotox Res 27: 199204. doi:10.1007/s12640-014-9503-y

Hinshaw HC, Feldman WH. 1945. Streptomycin in treatment of clinical tuberculosis: A preliminary report. Proc Mayo Clin 20: 313-318.

Hobbie SN, Bruell CM, Akshay S, Kalapala SK, Shcherbakov D, Bottger EC. 2008. Mitochondrial deafness alleles confer misreading of the genetic code. Proc Natl Acad Sci 105: 3244-3249. doi:10.1073/pnas.0707265105

Huang Y, Xie K, Li J, Xu N, Gong G, Wang G, Yu Y, Dong H, Xiong L. 2011. Beneficial effects of hydrogen gas against spinal cord ischemia-reperfusion injury in rabbits. Brain Res 1378: 125-136. doi:10.1016/j.brainres.2010.12.071

Huth ME, Ricci AJ, Cheng AG. 2011. Mechanisms of aminoglycoside ototoxicity and targets of hair cell protection. Int J Otolaryngol 2011: 937861.

Huth ME, Han KH, Sotoudeh K, Hsieh YJ, Effertz T, Vu AA, Verhoeven S, Hsieh MH, Greenhouse R, Cheng AG, et al. 2015. Designer aminoglycosides prevent cochlear hair cell loss and hearing loss. J Clin Invest 125: 583-592. doi:10.1172/JCI77424

Janas JD, Cotanche DA, Rubel EW. 1995. Avian cochlear hair cell regeneration: Stereological analyses of damage and recovery from a single high dose of gentamicin. Hear Res 92: 17-29. doi:10.1016/0378-5955(95)00190-5

Jiang H, Sha SH, Schacht J. 2005. NF- $\kappa B$ pathway protects cochlear hair cells from aminoglycoside-induced ototoxicity. J Neurosci Res 79: 644-651. doi:10.1002/jnr.20392 
Jiang M, Karasawa T, Steyger PS. 2017. Aminoglycosideinduced cochleotoxicity: A review. Front Cell Neurosci 11: 308. doi:10.3389/fncel.2017.00308

Jing W, Zongjie H, Denggang F, Na H, Bin Z, Aifen Z, Xijiang H, Cong Y, Yunping D, Ring HZ, et al. 2015. Mitochondrial mutations associated with aminoglycoside ototoxicity and hearing loss susceptibility identified by meta-analysis. J Med Genet 52: 95-103. doi:10.1136/ jmedgenet-2014-102753

Kalinec F. 2005. High-throughput screening of ototoxic and otoprotective pharmacological drugs. The Volta Review 105: $385-408$

Kalinec GM, Webster P, Lim DJ, Kalinec F. 2003. A cochlear cell line as an in vitro system for drug ototoxicity screening. Audiol Neurotol 8: 177-189. doi:10.1159/000071059

Karasawa T, Steyger PS. 2015. An integrated view of cisplatin-induced nephrotoxicity and ototoxicity. Toxicol Lett 237: 219-227. doi:10.1016/j.toxlet.2015.06.012

Karasawa T, Wang Q, Fu Y, Cohen DM, Steyger PS. 2008. TRPV4 enhances the cellular uptake of aminoglycoside antibiotics. J Cell Sci 121: 2871-2879. doi:10.1242/jcs. 023705

Karasawa T, Wang Q, David LL, Steyger PS. 2010. CLIMP-63 is a gentamicin-binding protein that is involved in drug induced cytotoxicity. Cell Death Dis 1: e102. doi:10.1038/ cddis. 2010.80

Karasawa T, Wang Q, David LL, Steyger PS. 2011. Calreticulin binds to gentamicin and reduces drug-induced ototoxicity. Toxicol Sci 124: 378-387. doi:10.1093/toxsci/ kfr196

Karasawa T, Sibrian-Vazquez M, Strongin RM, Steyger PS. 2013. Identification of cisplatin-binding proteins using agarose conjugates of platinum compounds. PLoS ONE 8: e66220. doi:10.1371/journal.pone.0066220

Karashima Y, Prenen J, Talavera K, Janssens A, Voets T, Nilius B. 2010. Agonist-induced changes in $\mathrm{Ca}^{2+}$ permeation through the nociceptor cation channel TRPA1. Biophys J 98: 773-783. doi:10.1016/j.bpj.2009.11.007

Kenyon EJ, Kirkwood NK, Kitcher SR, O’Reilly M, Derudas M, Cantillon DM, Goodyear RJ, Secker A, Baxendale S, Bull JC, et al. 2017. Identification of ion-channel modulators that protect against aminoglycoside-induced hair cell death. JCI Insight 2: 96773. doi:10.1172/jci.insight. 96773

Kim SH, Jung G, Kim S, Koo JW. 2018. Novel peptide vaccine GV1001 rescues hearing in kanamycin/furosemidetreated mice. Front Cell Neurosci 12: 3. doi:10.3389/ fncel.2018.00003

Kimitsuki T, Nakagawa T, Hisashi K, Komune S, Komiyama S. 1993. Cisplatin blocks mechano-electric transducer current in chick cochlear hair cells. Hear Res 71: 64-68. doi:10.1016/0378-5955(93)90021-R

Kimitsuki T, Nakagawa T, Hisashi K, Komune S, Uemura T. 1994. The effects of ototoxic drugs on mechano-electric transduction channels in chick cochlear hair cells. Eur Arch Otorhinolaryngol 251 (Suppl 1): S53-S56. doi:10. 1007/BF02565220

Kirkwood NK, O’Reilly M, Derudas M, Kenyon EJ, Huckvale R, van Netten SM, Ward SE, Richardson GP, Kros CJ 2017. D-Tubocurarine and berbamine: Alkaloids that are permeant blockers of the hair cell's mechano-electrical transducer channel and protect from aminoglycoside tox-
Drug-Induced Ototoxicity and Otoprotection

icity. Front Cell Neurosci 11: 262. doi:10.3389/fncel. 2017.00262

Kokong DD, Bakari A, Ahmad BM. 2014. Ototoxicity in Nigeria: Why it persists. Ear Nose Throat J 93: 256-264.

Koo JW, Quintanilla-Dieck L, Jiang M, Liu J, Urdang ZD, Allensworth JJ, Cross CP, Li H, Steyger PS. 2015. Endotoxemia-mediated inflammation potentiates aminoglycoside-induced ototoxicity. Sci Transl Med 7: 298ra118. doi:10.1126/scitranslmed.aac5546

Kusaba T, Lalli M, Kramann R, Kobayashi A, Humphreys BD. 2014. Differentiated kidney epithelial cells repair injured proximal tubule. Proc Natl Acad Sci 111: 15271532. doi:10.1073/pnas. 1310653110

Laurell G, Ekborn A, Viberg A, Canlon B. 2007. Effects of a single high dose of cisplatin on the melanocytes of the stria vascularis in the guinea pig. Audiol Neurotol 12: 170-178. doi:10.1159/000099020

Leitner MG, Halaszovich CR, Oliver D. 2011. Aminoglycosides inhibit KCNQ4 channels in cochlear outer hair cells via depletion of phosphatidylinositol $(4,5)$ bisphosphate. Mol Pharmacol 79: 51-60. doi:10.1124/mol.110.068130

Lestner JM, Hill LF, Heath PT, Sharland M. 2016. Vancomycin toxicity in neonates: A review of the evidence. Curr Opin Infect Dis 29: 237-247. doi:10.1097/QCO.00000 00000000263

Li H, Steyger PS. 2011. Systemic aminoglycosides are trafficked via endolymph into cochlear hair cells. Sci Rep 1: 159. doi:10.1038/srep00159

Li H, Kachelmeier A, Furness DN, Steyger PS. 2015. Local mechanisms for loud sound-enhanced aminoglycoside entry into outer hair cells. Front Cell Neurosci 9: 130.

Liu K, Jiang X, Shi C, Shi L, Yang B, Shi L, Xu Y, Yang W, Yang S. 2013. Cochlear inner hair cell ribbon synapse is the primary target of ototoxic aminoglycoside stimuli. Mol Neurobiol 48: 647-654. doi:10.1007/s12035-0138454-2

Liu J, Kachelmeier A, Dai C, Li H, Steyger PS. 2015a. Uptake of fluorescent gentamicin by peripheral vestibular cells after systemic administration. PLoS ONE 10: e0120612.

Liu K, Chen D, Guo W, Yu N, Wang X, Ji F, Hou Z, Yang WY, Yang S. 2015b. Spontaneous and partial repair of ribbon synapse in cochlear inner hair cells after ototoxic withdrawal. Mol Neurobiol 52: 1680-1689. doi:10.1007/ s12035-014-8951-y

Liu H, Li Y, Chen L, Zhang Q, Pan N, Nichols DH, Zhang WJ, Fritzsch B, He DZ. 2016. Organ of Corti and stria vascularis: Is there an interdependence for survival? PLoS ONE 11: e0168953.

Lombardi D, Becherucci F, Romagnani P. 2016. How much can the tubule regenerate and who does it? An open question. Nephrol Dial Transplant 31: 1243-1250. doi:10.1093/ndt/gfv262

Lorito G, Hatzopoulos S, Laurell G, Campbell KC, Petruccelli J, Giordano P, Kochanek K, Sliwa L, Martini A, Skarzynski H. 2011. Dose-dependent protection on cisplatininduced ototoxicity - an electrophysiological study on the effect of three antioxidants in the Sprague-Dawley rat animal model. Med Sci Monit 17: BR179-BR186. doi: 10.12659/MSM.881894 
Lugassy G, Shapira A. 1996. A prospective cohort study of the effect of vincristine on audition. Anticancer Drugs 7: 525-526. doi:10.1097/00001813-199607000-00005

Majumder P, Moore PA, Richardson GP, Gale JE. 2017. Protecting mammalian hair cells from aminoglycosidetoxicity: Assessing phenoxybenzamine's potential. Front Cell Neurosci 11: 94. doi:10.3389/fncel.2017.00094

Marcotti W, van Netten SM, Kros CJ. 2005. The aminoglycoside antibiotic dihydrostreptomycin rapidly enters mouse outer hair cells through the mechano-electrical transducer channels. J Physiol 567: 505-521. doi:10.1113/jphy siol.2005.085951

Matt T, Ng CL, Lang K, Sha SH, Akbergenov R, Shcherbakov D, Meyer M, Duscha S, Xie J, Dubbaka SR, et al. 2012. Dissociation of antibacterial activity and aminoglycoside ototoxicity in the 4-monosubstituted 2-deoxystreptamine apramycin. Proc Natl Acad Sci 109: 10984-10989. doi:10.1073/pnas.1204073109

May LA, Kramarenko II, Brandon CS, Voelkel-Johnson C, Roy S, Truong K, Francis SP, Monzack EL, Lee FS, Cunningham LL. 2013. Inner ear supporting cells protect hair cells by secreting HSP70. J Clin Invest 123: 3577-3587. doi:10.1172/JCI68480

McAlpine D, Johnstone BM. 1990. The ototoxic mechanism of cisplatin. Hear Res 47: 191-203. doi:10.1016/03785955(90)90151-E

Miller JJ. 1985. Handbook of ototoxicity. CRC, Boca Raton.

More SS, Akil O, Ianculescu AG, Geier EG, Lustig LR, Giacomini KM. 2010. Role of the copper transporter, CTR1, in platinum-induced ototoxicity. J Neurosci 30: 95009509. doi:10.1523/jneurosci.1544-10.2010

Mukherjea D, Whitworth CA, Nandish S, Dunaway GA, Rybak LP, Ramkumar V. 2006. Expression of the kidney injury molecule 1 in the rat cochlea and induction by cisplatin. Neuroscience 139: 733-740. doi:10.1016/j.neu roscience.2005.12.044

Mukherjea D, Jajoo S, Whitworth C, Bunch JR, Turner JG, Rybak LP, Ramkumar V. 2008. Short interfering RNA against transient receptor potential vanilloid 1 attenuates cisplatin-induced hearing loss in the rat. J Neurosci 28: 13056-13065. doi:10.1523/jneurosci.1307-08.2008

Mukherjea D, Jajoo S, Sheehan K, Kaur T, Sheth S, Bunch J, Perro C, Rybak LP, Ramkumar V. 2011. NOX3 NADPH oxidase couples transient receptor potential vanilloid 1 to signal transducer and activator of transcription 1-mediated inflammation and hearing loss. Antioxid Redox Signal 14: 999-1010. doi:10.1089/ars.2010.3497

Myrdal SE, Steyger PS. 2005. TRPV1 regulators mediate gentamicin penetration of cultured kidney cells. Hear Res 204: 170-182. doi:10.1016/j.heares.2005.02.005

Nagata K, Duggan A, Kumar G, Garcia-Anoveros J. 2005. Nociceptor and hair cell transducer properties of TRPA1, a channel for pain and hearing. J Neurosci 25: 4052-4061. doi:10.1523/jneurosci.0013-05.2005

Naughton CA. 2008. Drug-induced nephrotoxicity. Am Fam Physician 78: 743-750.

Nicol KM, Hackney CM, Evans EF, Pratt SR. 1992. Behavioural evidence for recovery of auditory function in guinea pigs following kanamycin administration. Hear Res 61: 117-131. doi:10.1016/0378-5955(92)90042-L
Nilius B, Szallasi A. 2014. Transient receptor potential channels as drug targets: from the science of basic research to the art of medicine. Pharmacol Rev 66: 676-814. doi: 10.1124/pr.113.008268

Oh GS, Kim HJ, Choi JH, Shen A, Kim CH, Kim SJ, Shin SR, Hong SH, Kim Y, Park C, et al. 2011. Activation of lipopolysaccharide-TLR4 signaling accelerates the ototoxic potential of cisplatin in mice. J Immunol 186: 11401150. doi:10.4049/jimmunol.1002183

Oishi N, Duscha S, Boukari H, Meyer M, Xie J, Wei G, Schrepfer T, Roschitzki B, Boettger EC, Schacht J. 2015. XBP1 mitigates aminoglycoside-induced endoplasmic reticulum stress and neuronal cell death. Cell Death Dis 6: e1763. doi:10.1038/cddis.2015.108

Owens KN, Santos F, Roberts B, Linbo T, Coffin AB, Knisely AJ, Simon JA, Rubel EW, Raible DW. 2008. Identification of genetic and chemical modulators of zebrafish mechanosensory hair cell death. PLoS Genet 4: e1000020. doi:10.1371/journal.pgen.1000020

Paken J, Govender CD, Pillay M, Sewram V. 2016. Cisplatinassociated ototoxicity: A review for the health professional. J Toxicol 2016: 1809394. doi:10.1155/2016/1809394

Pan B, Akyuz N, Liu XP, Asai Y, Nist-Lund C, Kurima K, Derfler BH, Gyorgy B, Limapichat W, Walujkar S, et al. 2018. TMC1 forms the pore of mechanosensory transduction channels in vertebrate inner ear hair cells. Neuron 99: 736-753.e6. doi:10.1016/j.neuron.2018.07.033

Pitiriga V, Dimitroulia E, Saroglou G, Tsakris A. 2017. The challenge of curbing aminoglycoside resistance: Can antimicrobial stewardship programs play a critical role? $E x$ pert Rev Anti Infect Ther 15: 947-954. doi:10.1080/ 14787210.2017.1382355

Prayuenyong P, Taylor JA, Pearson SE, Gomez R, Patel PM, Hall DA, Kasbekar AV, Baguley DM. 2018. Vestibulotoxicity associated with platinum-based chemotherapy in survivors of cancer: A scoping review. Front Oncol 8: 363. doi:10.3389/fonc.2018.00363

Qian Y, Guan MX. 2009. Interaction of aminoglycosides with human mitochondrial $12 \mathrm{~S}$ rRNA carrying the deafness-associated mutation. Antimicrob Agents Chemother 53: 4612-4618. doi:10.1128/AAC.00965-08

Ramakrishnan R, Jusko WJ. 2001. Interactions of aspirin and salicylic acid with prednisolone for inhibition of lymphocyte proliferation. Int Immunopharmacol 1: 2035-2042. doi:10.1016/S1567-5769(01)00132-1

Ramaswamy B, Roy S, Apolo AB, Shapiro B, Depireux DA. 2017. Magnetic nanoparticle mediated steroid delivery mitigates cisplatin induced hearing loss. Front Cell Neurosci 11: 268. doi:10.3389/fncel.2017.00268

Ross CJ, Katzov-Eckert H, Dube MP, Brooks B, Rassekh SR, Barhdadi A, Feroz-Zada Y, Visscher H, Brown AM, Rieder MJ, et al. 2009. Genetic variants in TPMT and COMT are associated with hearing loss in children receiving cisplatin chemotherapy. Nat Genet 41: 1345-1349. doi: $10.1038 /$ ng.478

Roy S, Ryals MM, van den Bruele AB, Fitzgerald TS, Cunningham LL. 2013. Sound preconditioning therapy inhibits ototoxic hearing loss in mice. J Clin Invest 123: 4945-4949. doi:10.1172/JCI71353

Rybak LP. 1993. Ototoxicity of loop diuretics. Otolaryngol Clin North Am 26: 829-844. 
Salt AN, Plontke SK. 2009. Principles of local drug delivery to the inner ear. Audiol Neurotol 14: 350-360. doi: $10.1159 / 000241892$

Schacht J, Talaska AE, Rybak LP. 2012. Cisplatin and aminoglycoside antibiotics: Hearing loss and its prevention. Anat Rec (Hoboken) 295: 1837-1850. doi:10.1002/ar. 22578

Schatz A, Bugie E, Waksman SA. 1944. Streptomycin, a substance exhibiting antibiotic activity against gram-positive and gram-negative bacteria. Clin Orthop Relat Res 437: 3-6.

Sha SH, Schacht J. 1999. Salicylate attenuates gentamicininduced ototoxicity. Lab Invest 79: 807-813.

Sha SH, Qiu JH, Schacht J. 2006. Aspirin to prevent gentamicin-induced hearing loss. N Engl J Med 354: 18561857. doi:10.1056/NEJMc053428

Siddik ZH. 2003. Cisplatin: Mode of cytotoxic action and molecular basis of resistance. Oncogene 22: 7265-7279. doi:10.1038/sj.onc.1206933

Slattery EL, Warchol ME. 2010. Cisplatin ototoxicity blocks sensory regeneration in the avian inner ear. J Neurosci 30: 3473-3481. doi:10.1523/jneurosci.4316-09.2010

Slattery EL, Oshima K, Heller S, Warchol ME. 2014. Cisplatin exposure damages resident stem cells of the mammalian inner ear. Dev Dyn 243: 1328-1337. doi:10.1002/ dvdy. 24150

Sluyter S, Klis SF, de Groot JC, Smoorenburg GF. 2003. Alterations in the stria vascularis in relation to cisplatin ototoxicity and recovery. Hear Res 185: 49-56. doi: 10.1016/S0378-5955(03)00260-0

Somdas MA, Korkmaz F, Gurgen SG, Sagit M, Akcadag A. 2015. $\mathrm{N}$-acetylcysteine prevents gentamicin ototoxicity in a rat model. J Int Adv Otol 11: 12-18. doi:10.5152/ iao. 2015.650

Stepanyan RS, Indzhykulian AA, Vélez-Ortega AC, Boger ET, Steyger PS, Friedman TB, Frolenkov GI. 2011. TRPA1-mediated accumulation of aminoglycosides in mouse cochlear outer hair cells. J Assoc Res Otolaryngol 12: 729-740. doi:10.1007/s10162-011-0288-x

Taleb M, Brandon CS, Lee FS, Lomax MI, Dillmann WH, Cunningham LL. 2008. Hsp70 inhibits aminoglycosideinduced hair cell death and is necessary for the protective effect of heat shock. J Assoc Res Otolaryngol 9: 277-289. doi:10.1007/s10162-008-0122-2

Tate AD, Antonelli PJ, Hannabass KR, Dirain CO. 2017. Mitochondria-targeted antioxidant mitoquinone reduces cisplatin-induced ototoxicity in guinea pigs. Otolaryngol Head Neck Surg 156: 543-548. doi:10.1177/019459 9816678381

Taylor RR, Nevill G, Forge A. 2008. Rapid hair cell loss: A mouse model for cochlear lesions. J Assoc Res Otolaryngol 9: 44-64. doi:10.1007/s10162-007-0105-8

Teitz T, Fang J, Goktug AN, Bonga JD, Diao S, Hazlitt RA, Iconaru L, Morfouace M, Currier D, Zhou Y, et al. 2018. CDK2 inhibitors as candidate therapeutics for cisplatinand noise-induced hearing loss. J Exp Med 215: 11871203. doi:10.1084/jem. 20172246

Thomas JP, Lautermann J, Liedert B, Seiler F, Thomale J. 2006. High accumulation of platinum-DNA adducts in strial marginal cells of the cochlea is an early event in
Drug-Induced Ototoxicity and Otoprotection

cisplatin but not carboplatin ototoxicity. Mol Pharmacol 70: 23-29.

Thomas AJ, Hailey DW, Stawicki TM, Wu P, Coffin AB, Rubel EW, Raible DW, Simon JA, Ou HC. 2013. Functional mechanotransduction is required for cisplatin-induced hair cell death in the zebrafish lateral line. J Neurosci 33: 4405-4414. doi:10.1523/jneurosci.3940-12.2013

Tran Ba Huy P, Bernard P, Schacht J. 1986. Kinetics of gentamicin uptake and release in the rat. Comparison of inner ear tissues and fluids with other organs. JClin Invest 77: 1492-1500. doi:10.1172/JCI112463

Trung NT, Hien TT, Huyen TT, Quyen DT, Van Son T, Hoan PQ, Phuong NT, Lien TT, Binh MT, Van Tong H, et al. 2016. Enrichment of bacterial DNA for the diagnosis of blood stream infections. BMC Infect Dis 16: 235. doi: 10.1186/s12879-016-1568-1

Tucci DL, Rubel EW. 1990. Physiologic status of regenerated hair cells in the avian inner ear following aminoglycoside ototoxicity. Otolaryngol Head Neck Surg 103: 443-450. doi:10.1177/019459989010300317

Turan M, Ciger E, Arslanoglu S, Borekci H, Onal K. 2017. Could edaravone prevent gentamicin ototoxicity? An experimental study. Hum Exp Toxicol 36: 123-127. doi:10.1177/0960327116639360

van Hecke R, van Rompaey V, Wuyts FL, Leyssens L, Maes L. 2017. Systemic aminoglycosides-induced vestibulotoxicity in humans. Ear Hear 38: 653-662. doi:10.1097/ AUD.0000000000000458

van Netten SM, Kros CJ. 2007. Insights into the pore of the hair cell transducer channel from experiments with permeant blockers. Curr Top Membr 59: 375-398. doi:10.1016/S1063-5823(06)59013-1

van Ruijven MW, de Groot JC, Hendriksen F, Smoorenburg GF. 2005. Immunohistochemical detection of platinated DNA in the cochlea of cisplatin-treated guinea pigs. Hear Res 203: 112-121. doi:10.1016/j.heares.2004.12.007

Velez-Ortega AC, Freeman MJ, Indzhykulian AA, Grossheim JM, Frolenkov GI. 2017. Mechanotransduction current is essential for stability of the transducing stereocilia in mammalian auditory hair cells. eLife 6: e24661.

Vu AA, Nadaraja GS, Huth ME, Luk L, Kim J, Chai R, Ricci AJ, Cheng AG. 2013. Integrity and regeneration of mechanotransduction machinery regulate aminoglycoside entry and sensory cell death. PLOS ONE 8: e54794. doi:10.1371/journal.pone.0054794

Waissbluth S, Daniel SJ. 2013. Cisplatin-induced ototoxicity: Transporters playing a role in cisplatin toxicity. Hear Res 299: 37-45. doi:10.1016/j.heares.2013.02.002

Wang J, Van De Water TR, Bonny C, de Ribaupierre F, Puel JL, Zine A. 2003. A peptide inhibitor of c-Jun N-terminal kinase protects against both aminoglycoside and acoustic trauma-induced auditory hair cell death and hearing loss. J Neurosci 23: 8596-8607. doi:10.1523/jneurosci.23-2408596.2003

Wang J, Ladrech S, Pujol R, Brabet P, Van De Water TR, Puel JL. 2004. Caspase inhibitors, but not c-Jun $\mathrm{NH}_{2}$-terminal kinase inhibitor treatment, prevent cisplatin-induced hearing loss. Cancer Res 64: 9217-9224. doi:10.1158/ 0008-5472.CAN-04-1581

Wangemann P. 2006. Supporting sensory transduction: Cochlear fluid homeostasis and the endocochlear potential. $J$ Physiol 576: 11-21. doi:10.1113/jphysiol.2006.112888 
C.J. Kros and P.S. Steyger

Wangemann P, Schacht J. 1996. Homeostatic mechanisms in the cochlea. In The cochlea (ed. Dallos P, Popper AN, Fay RR), pp. 130-185. Springer, New York.

Warchol ME. 2010. Cellular mechanisms of aminoglycoside ototoxicity. Curr Opin Otolaryngol Head Neck Surg 18: 454-458. doi:10.1097/MOO.0b013e32833e05ec

Woolley SM, Wissman AM, Rubel EW. 2001. Hair cell regeneration and recovery of auditory thresholds following aminoglycoside ototoxicity in Bengalese finches. Hear Res 153: 181-195. doi:10.1016/S0378-5955(00)00217-3

Wu WJ, Sha SH, McLaren JD, Kawamoto K, Raphael Y, Schacht J. 2001. Aminoglycoside ototoxicity in adult CBA, C57BL and BALB mice and the Sprague-Dawley rat. Hear Res 158: 165-178. doi:10.1016/S0378-5955 (01)00303-3

Yamashita D, Jiang HY, Schacht J, Miller JM. 2004. Delayed production of free radicals following noise exposure Brain Res 1019: 201-209. doi:10.1016/j.brainres.2004. 05.104
Yang CH, Liu Z, Dong D, Schacht J, Arya D, Sha SH. 2017. Histone deacetylase inhibitors are protective in acute but not in chronic models of ototoxicity. Front Cell Neurosci 11: 315. doi:10.3389/fncel.2017.00315

Yorgason JG, Kalinec GM, Luxford WM, Warren FM, Kalinec F. 2010. Acetaminophen ototoxicity after acetaminophen/hydrocodone abuse: Evidence from two parallel in vitro mouse models. Otolaryngol Head Neck Surg 142: 814-819, 819.e1-2. doi:10.1016/j.otohns.2010.01.010

Zhang YB, Zhang R, Zhang WF, Steyger PS, Dai CF. 2012 Uptake of gentamicin by vestibular efferent neurons and superior olivary complex after transtympanic administration in guinea pigs. Hear Res 283: 169-179. doi:10.1016/j. heares.2011.10.003

Zheng J, Dai C, Steyger PS, Kim Y, Vass Z, Ren T, Nuttall AL. 2003. Vanilloid receptors in hearing: Altered cochlear sensitivity by vanilloids and expression of TRPV1 in the organ of corti. J Neurophysiol 90: 444-455. doi:10.1152/ jn.00919.2002 


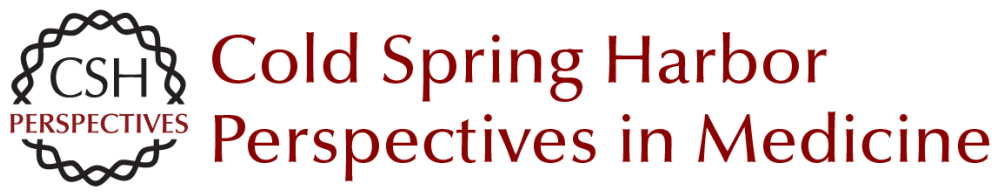

\section{Aminoglycoside- and Cisplatin-Induced Ototoxicity: Mechanisms and Otoprotective Strategies}

Corné J. Kros and Peter S. Steyger

Cold Spring Harb Perspect Med 2019; doi: 10.1101/cshperspect.a033548 originally published online December 17, 2018

Subject Collection Function and Dysfunction of the Cochlea

Hidden Hearing Loss: A Disorder with Multiple

Etiologies and Mechanisms

David C. Kohrman, Guoqiang Wan, Luis Cassinotti, et al.

Hair Cell Afferent Synapses: Function and

Dysfunction

Stuart L. Johnson, Saaid Safieddine, Mirna Mustapha, et al.

Active Biomechanics of Sensory Hair Bundles Dolores Bozovic

The Tectorial Membrane: Mechanical Properties and Functions Jonathan B. Sellon, Roozbeh Ghaffari and Dennis M. Freeman

The Epidemiology of Deafness Abraham M. Sheffield and Richard J.H. Smith

Toward the Optical Cochlear Implant Tobias Dombrowski, Vladan Rankovic and Tobias Moser

Outer Hair Cells and Electromotility Jonathan Ashmore

Interactions between Macrophages and the Sensory Cells of the Inner Ear Mark E. Warchol
Development and Patterning of the Cochlea: From

Convergent Extension to Planar Polarity Mireille Montcouquiol and Matthew W. Kelley

Hair-Bundle Links: Genetics as the Gateway to Function Guy P. Richardson and Christine Petit

Aminoglycoside- and Cisplatin-Induced Ototoxicity: Mechanisms and Otoprotective Strategies Corné J. Kros and Peter S. Steyger

Function and Dysfunction of TMC Channels in Inner Ear Hair Cells

David P. Corey, Nurunisa Akyuz and Jeffrey R. Holt

Cochlear Gene Therapy Lawrence Lustig and Omar Akil

Age-Related Hearing Loss

Michael R. Bowl and Sally J. Dawson

Inner Ear Connexin Channels: Roles in Development and Maintenance of Cochlear Function Fabio Mammano

A Functional Perspective on the Evolution of the Cochlea Christine Köppl and Geoffrey A. Manley

For additional articles in this collection, see http://perspectivesinmedicine.cshlp.org/cgi/collection/ 